\title{
On some New British Marine Algae.
}

\author{
BY \\ E. A. L. BATTERS, B.A., LL.B., F.L.S. \\ With Plate XI.
}

URING the last few months a large number of species have been added to the Marine Flora of Britain, and I propose in the present paper to give descriptions of such of them as have either never been previously described or have only been described in my preliminary note on a previous page of this volume ${ }^{1}$.

Buffhamia speciosa, Batt. 1.c.

I found this species, which I have named after Mr. T. H. Buffham who has done so much to increase our knowledge of the reproductive organs of the Florideae, at Weymouth in I 892. In September of that year I gathered a considerable quantity of Castagnea Griffithsiana, J. Ag., in the hope of finding plurilocular sporangia, which up to the present time have not been found on that species, the systematic position of which must in consequence remain doubtful. Although I did not succeed in finding the gametangia of the Castagnea, my labour was not thrown away, as most of the specimens I then gathered were more or less covered with epiphytic

1 Annals of Botany, Vol. ix, p. I68, 1895.

[Annals of Botany, Vol. IX. No. XXXIV. June, 1895.] 
Algae, amongst which Microcoryne ocellata, Strömf.--an Alga up to that time known only from a single Norwegian locality, and, I believe, only once found there by the late Dr. Strömfelt, the founder of the genus-and Buffhamia speciosa are especially worthy of mention. I found these two species frequently growing side by side on the same branch of Castagnea Griffithsiana, and I think it worth noticing that, whilst in the host-plant the asexual unilocular sporangia are the only reproductive organs known, in both the epiphytes plurilocular sporangia are alone found. In substance and colour, and more or less in structure, the fertile fronds of Buffhamia resemble the simple branches of the host-plant, and at first I thought I had really found the long-looked-for gametangia of Castagnea Griffithsiana; but a closer examination at once undeceived me, the junction between host and epiphyte being clearly marked, to say nothing of the entirely different development of the two plants. I may here mention that, whilst I have seen Microcoryne ocellata on a variety of other hosts, e.g. Chorda Filum, the original host-plant on which Dr. Strömfelt found it, Rhodymenia palmata, Zostera marina, \&c., I have up to the present found Buffhamia only on Castagnea Griffithsiana, although I have carefully searched for it on the other plants which usually accompany that species.

Buffhamia speciosa occurs either in single isolated specimens or, much more frequently, in groups of from one or two to fifty or a hundred individuals, the epiphyte often covering a branch of the host-plant for the distance of an inch or more with a thick fringe of its tiny fronds. The olive-brown cylindrical fronds are always perfectly simple, and taper more or less to both base and apex. They vary in length from a quarter to an inch and a half in length, and are generally about $\mathrm{I} \mathrm{mm}$. in breadth. As has been already said, when mature and fertile they resemble the branches of the hostplant in some respects, though when young the fronds in no way resemble a Castagnea, but are much more like sterile specimens of Asperococcus or Scytosiphon in general appear- 
ance. At first the young frond consists of a single row of cells which, by transverse and longitudinal division, very soon forms a solid axis of large, hyaline, more or less angular roundish cells surrounded by a cortical layer of much smaller cells furnished with numerous small disc-shaped chromatophores. When the fronds have reached a few lines in length, the cortical filaments first make their appearance, commencing at the apex of the frond and gradually spreading downwards till the entire frond, with the exception of the basal portion, is covered. The base of the frond always remains slender, often consisting of a single row of cells, and is thickly covered with descending rhizoidal filaments, which, creeping between the cortical filaments of the host-plant, securely anchor the epiphyte in position. Hyaline hairs of the usual type are plentifully scattered between the cortical filaments. The slender assimilatory filaments are either simple or forked and are slightly clavate; they generally consist of from three to seven cells about $9 \mu$ in diameter. The cells vary in length from $10-18 \mu$, the longer being mixed with the shorter ones without any apparent regard to position, the terminal cell being either longer than the rest or slightly shorter than those immediately below it.

Plurilocular sporangia are borne among the cortical filaments, and are either linear-oblong or spindle-shaped, obtuse or pointed, and always more or less evidently stalked; sporangia consisting of a single row of superimposed cells are frequently met with. In length the sporangia vary from $50-75 \mu$ or even longer; the diameter is usually about $15 \mu$. In some specimens the sporangia are as long as the cortical filaments, whilst in others they are rather shorter.

Growth is basal. Very young specimens usually terminate in one or two hyaline hairs.

Relying on the structure of the mature frond, I have, in the note above referred to, placed Buffhamia in the Chordariaceae : but, taking the development into consideration, I should probably have done better had I made it the type of a new family, Buffhamiaceae. 
In typical members of the Chordariaceae, e.g. Castagnea virescens, C. Zosterae, Microcoryne ocellata (and according to Farlow, Chordaria divaricata), the frond at first appears as a roundish spot, composed of a single layer of cells, from which a tuft of vertical filaments, ending in hairs, arises. These vertical filaments generally produce clusters of moniliform coloured filaments only on one side-that most distant from the centre of the tuft-while on the side turned to the centre of the tuft, at a later period, rhizoidal filaments are formed which bind the separate individual filaments of which the tuft is composed into a compound frond. The frond of such a plant as Castagnea virescens is therefore a collection of originally independent filaments which have become twisted together and partially united by means of the rhizoidal filaments, the secund groups of moniliform filaments forming what appears to be a distinct cortical layer. In Buffhamia, on the other hand, the frond is not in any sense of the word compound. As has been shown, the young frond consists of a few superimposed cells, ending in a hair; by transverse and longitudinal division a solid axis is formed, surrounded by a layer of smaller cells, from which, at a later period, the cortical filaments arise. It will, therefore, be seen that although Buffhamia in its mature state closely resembles the members of the Chordariaceae, in its earlier stages it shows a closer relationship with Asperococcaceae, or, through Myriotrichia densa, with the Myriotrichaceae. It appears, therefore, best to regard it as the type of a distinct family, which may be thus characterized.

\section{Buffhamiaceae, Nov. Fam.}

Fronds cylindrical, simple, more or less gelatinous, with an axis of large colourless cells surrounded by smaller coloured cells, from which arise colourless hairs, and, at maturity, numerous short, simple or forked, jointed assimilatory filaments (paraphyses), densely covering the whole surface of the frond, with the exception of the basal portion; plurilocular sporangia linear-oblong or spindle-shaped, borne between the 
assimilatory filaments: chromatophores numerous, small, disc-shaped: growth basal.

Buffhamia, Batt. Characters of the family.

Buffhamia speciosa, Batt. Fronds olive-brown, solitary or gregarious, attached to the host-plant by rhizoidal filaments, more or less gelatinous and lubricous, from a quarter to one and a quarter inch long, and about $\mathrm{I} \mathrm{mm}$. in diameter, filiform, tapering to both base and apex, solid ; assimilatory filaments (paraphyses) few-celled, cylindrical or slightly club-shaped; plurilocular sporangia linear-oblong or spindle-shaped, stalked, as long as or rather shorter than the assimilatory filaments, frequently composed of a single row of cells.

Epiphytic on the fronds of Castagnea Griffithsiana near low-water mark; Weymouth. Fructification in Autumn.

Myriotrichia densa, Batt. 1. c.

This species appears to be widely distributed along the coasts of Britain, for I have found it at Lamlash and Cumbrae in the North and Weymouth and Swanage in the South, and I believe it to be not uncommon, at any rate in certain seasons, all along the South coast.

In general appearance Myriotrichia densa more resembles Litosiphon pusillus than $M$. clavaeformis, Harv., and I have no doubt that it has often been mistaken for that species. The mature fronds are cylindrical in outline, and are of almost the same diameter from base to apex, with the exception of a very small space near the base which is usually bare of branches.

As in the other species of Myriotrichia, the fronds are at first composed of a single row of cells which by transverse and longitudinal division form a solid axis from which the short horizontal branches arise. The branches bear closely set, erect, dichotomous or secund ramuli. In a section of the frond these radiating branches are seen to be closely rebranched, the divisions erect and level-topped, giving to the axis the appearance of being surrounded by closely set stalked groups of peripheral filaments. 
There is a variety of $M$. clavaeformis, which I have called var. subcylindrica, which outwardly closely resembles $M$. densa, but in this variety the branches are either perfectly simple or bear only one or two short patent secondary branches. In $M$. densa the plurilocular sporangia are either isolated or collected into little groups of from two to four, they are stalked, about 40 or $50 \mu$ long and from 6-10 $\mu$ wide ; they usually contain but a single row of cells. In the other two British species of Myriotrichia, the plurilocular sporangia are usually sessile and conical, containing three or four tiers of cells, and the unilocular sporangia are always sessile; while in $M$. densa the plurilocular sporangia are stalked, elongated, and frequently contain as many as a dozen tiers, and the unilocular sporangia are stalked; the radiating branches, moreover, are much more evidently moniliform in $M$. densa than in the other species. The British species of Myriotrichia, with their principal varieties, may be grouped thus :-

A. Axis clothed throughout with radiating branches; plurilocular sporangia conical or elongated, not collected into dense masses.

I. Upper branches longer than lower and bearing a few patent secondary branches.

a. Branches few and scattered; plant small, from $\frac{1}{8}-\frac{1}{4}$ inch long. M. clavaeformis, Harv. var. minima, Holm. et Batt.

$\beta$. Branches numerous, closely set; plant from $\frac{1}{2}$ to $I \frac{1}{2}$ inch long. M. clavaeformis, Harv. var. typica.

II. Branches of nearly equal length throughout the entire length of the frond.

a. Horizontal branches bearing closely dichotomous, or secund level-topped secondary branches ; sporangia stalked, gametangia elongated. $M$. densa.

$\beta$. Horizontal branches simple or bearing only one or two patent secondary branches; sporangia sessile, gametangia conical. $M$. clavaeformis var. subcylindrica.

B. Axis clothed only at intervals with short simple 
branches; plurilocular sporangia broadly conical or ovoid, surrounding the axis with dense cushion-like masses. $M$. filiformis, Harv.

I propose to characterize $M$. densa as follows :-

Fronds dark olive-brown, almost black, cylindrical in outline, slightly attenuated at the base, from half an inch to an inch and a half in length and from $200-250 \mu$ in diameter, axis densely clothed throughout with short dichotomous or secund level-topped more or less moniliform secondary branches, hyaline hairs few or altogether wanting ; unilocular sporangia stalked, spherical or ovoid, about $50 \mu$ in diameter ; plurilocular sporangia cylindrical or lanceolate, $25-60 \mu$ long and $6-10 \mu$ in diameter, containing one or two rows of cells.

Thickly fringing the old fronds of Zostera marina. Weymouth, Cumbrae, Arran, E. A. B. ; Swanage, T. H. Buffham.

Tellamia contorta, Batt. 1. c.

At almost any station along our coasts shells of the common yellow periwinkle (Littorina obtusata, L.) may be found which have assumed a more or less deep olive-green colour. On examination with the microscope it will be found that this discoloration is caused by the presence of filiform Algae which penetrate the periostracum of the shell, but so far as I have been able to ascertain do not enter the calcareous portion of it. Although these Algae are usually found in abundance in shells inhabited by the living molluscs, where of course the periostracum is more or less perfect, I have not found them in dead shells, where it has been entirely worn away, so that I feel the more confident that these Algae confine their attacks to the periostracum, although they usually make their appearance, and no doubt find an entrance, where that membrane has been more or less eroded at the umbo. The presence of the Algae seems in no way to injure the shell, and may be of direct advantage to the mollusc, as the affected shells are much less conspicuous amongst the dark olive Fuci on which they are usually found than the bright yellow and consequently very noticeable healthy ones. 
When a piece of the periostracum of a periwinkle which has been attacked by the Alga is examined under the microscope, it appears to be almost entirely composed of the oval cells of the Tellamia, the filaments of which are contained within the membrane, the horizontal filaments creeping either just below the external surface of the periostracum or just above the surface of the chalky portion of the shell. In the former case very numerous short vertical branches, ending in a pointed apical cell, push their way downwards towards the interior of the shell, and, passing completely through the outer membrane, are stopped by the chalky shell, or, turning again at right angles, grow for a short distance parallel to the primary filaments. In the other case, i.e. where the primary filaments are situated nearer the interior surface of the periostracum than the exterior, the vertical branches are pushed upwards and terminate at the exterior surface of the membrane, which becomes quite rough and irregular, owing to its being pierced by the very numerous branches of the parasite. These vertical branches are frequently so close together that they appear to form a more or less parenchymatous membrane.

The branching of Tellamia contorta is so irregular as to defy description, appearing to run in all directions, and so closely are the various individual plants packed together and their branches so interwoven that it is almost impossible to say to which individual a particular branch belongs, the branches in many cases apparently, and perhaps really, anastomosing. In addition to the ordinary cells, which are usually $3^{-6} \mu$ in diameter and either oval or roundish, very much enlarged cells occur at irregular intervals in the moniliform filaments. These enlarged cells are either solitary or from two to a dozen or more together, and are always of a darker colour than the ordinary cells near them. These swollen cells do not appear to have any connexion with the reproduction of the plant, and are in all probability analogous to the enlarged cells in Ostreobium Qucketti. They vary a good deal in shape, but are usually oval or elongated, and are sometimes $40 \mu$ long by 
I $5 \mu$ in diameter. Very frequently the filaments which contain these abnormal cells are curved in a falcate manner or even rolled up into a nearly spherical mass.

The zoospores are formed in slightly enlarged cells hardly differing in appearance from the ordinary vegetative cells. When the young plant first appears it is generally rolled up in a ball; at a later period the end of the filament grows out at a tangent, and branches are then given off in all directions. The endochrome appears to be applied to the walls of the cells in an almost unbroken layer.

In my note ${ }^{1}$ on the genus Tellamia, I have referred to this genus, under the name Tellamia intricata, another Alga that usually accompanies Tellamia contorta and appears to be equally common. This plant, which is perhaps more closely related to Endoderma than to Tellamia, is much more slender than the plant above described, being seldom more than $3.5 \mu$ in diameter, and is never interwoven into such compact masses as that species. The filaments are branched in a rather irregular way, opposite alternate or secund. In nearly every case the cells are longer than broad, but they vary very much in length; generally they are from $3^{-I} 5 \mu$ long, but longer cells are not uncommon; the diameter of the filaments varies from $2 \cdot 5-4 \cdot 5 \mu$, occasionally the branches anastomose. No enlarged cells like those of Tellamia contorta were observed. Zoospores are formed in enlarged cells about $6 \mu$ in diameter. In this species the chromatophore nearly fills the entire cell, and is composed of an irregularly shaped layer broken here and there, and contains a single pyrenoid. The colour of the plant is yellowish green often almost brown. The genus Tellamia belongs to the Chaetophoraceae, and must be placed near the genus Endoderma. The genus may be thus characterised.

Tellamia. Thallus minute, consisting of radiating, irregularly branched, jointed, creeping filaments, living in the periostracum of mollusca; cells of the filaments often swollen and distorted. Zoospores formed in slightly enlarged cells.

\footnotetext{
1 Annals of Botany, Vol. ix, p. I69.
} 
Tellamia contorta. Filaments yellowish green or brown, very irregularly branched, branching both lateral and dorsiventral; horizontal branches frequently falcate or coiled into a nearly spherical mass, sometimes anastomosing; vertical branches close together often united laterally, ending in a sharply pointed cell ; cells 6-9 $\mu$ long, 3-10 $\mu$ in diameter; enlarged dark coloured cells $20 \mu$ or more in diameter not infrequent.

Probably common all round our shores. Cumbrae, Weymouth, E. A. B. ; Padstow, Falmouth, R. V. Tellam; Berwick, J. B.

Tellamia (Endoderma?) intricata. Filaments yellowish green, slender, branches long and slender, cells $2 \cdot 5-4 \cdot 5 \mu$ in diameter, 4-24 $\mu$ in length. Chromatophores parietal, each containing a single pyrenoid.

Probably common. Cumbrae and Weymouth, E. A. B.; Padstow and Falmouth, R. V. Tellam.

I have named this genus in honour of Mr. R. V. Tellam, of Bodmin, who has done much to increase our knowledge of the Flora of Cornwall and Devon.

Callocolax neglectus. Schmitz MSS. in Holmes, Alg. Brit. Exsicc. On page 229 of the second volume of his Flora of Berwick-upon-Tweed, published in $183 \mathrm{I}$, Dr. Geo. Johnston, speaking of Callophyllis, or as it was then called Halymenia laciniata, remarks, 'I have a specimen of this species, in which there are scattered irregularly over the frond small circular clusters of papillary tubercles about a line in height. The papillae contain minute oval granules, and each cluster or tuft is composed of about twenty papillae. It is a sort of fructification unnoticed by Dr. Greville, and perhaps affords a proof that characters drawn from the parts of fructification in the classification of the Algae, are only of subsidiary value.'

In the autumn of 1884 , when collecting at Berwick, and since then on several occasions, I have found similar specimens to the one described by Dr. Johnston. About two years ago, or rather more, the late Dr. F. Schmitz, who was then in 
England, told me he had found a new parasitic Floridean on Callophyllis laciniata: I then called his attention to the passage above quoted, and he told me that he felt sure the 'papillae' referred to by Johnston were really the fronds of his new parasite, which he proposed to call Callocolax. I showed my specimens to Mr. Holmes, and he has since found the plant in the south of England and has distributed specimens, though hardly very characteristic ones, in his excellent Algae Britannicae rariores exsiccatae. I may also mention that specimens of Buffhamia speciosa and Tellamia intricata have also been distributed in the same publication.

The fronds of this tiny parasite occur either in solitary specimens or in groups composed of from three or four to a dozen or more individuals, and are situated on any part of the host-plant. The fronds are from 2-4 $\mathrm{mm}$. in diameter and are rather irregular in shape, being either quite simple, or lobed, or palmate. The connexion between host and parasite is very intimate, the cells of the one blending almost imperceptibly with those of the other. Like Ricardia, Fanczereskia, Gonimophyllum, and so many other parasitic Florideae, Callocolax belongs to the same family as the host on which it grows; and no doubt this fact has caused it to be often overlooked, as the structure of the cystocarp is exactly like that of Callophyllis, and the dividing line between host and parasite very difficult to see. When, however, as often happens, the host bears cystocarps and the parasite tetraspores or vice versa, it is not so easy for the parasite to escape observation. In some cases the fronds of the Callocolax are darker coloured than those of the Callophyllis, and I have found this is usually the case when the former bears cystocarps and the latter tetraspores; in the converse case the fronds of the Callocolax are the lighter coloured. I have received from $\mathrm{Mr}$. T. H. Buffham tetrasporic specimens of this species plentifully scattered amongst the cystocarps, which they hardly exceed in size, of the host-plant; they are situated either on the edge or surface of the frond, and are 
easily recognisable even to the naked eye by their pale colour. The genus may be described thus.

Callocolax, Schmitz in Holmes Alg. Brit. rar. exsicc. vii. Minute parasitic Floridean growing on the fronds of Callophyllis, connexion between host and parasite very intimate, the cells of the one more or less blending with those of the other. Fructification as in Callophyllis.

\section{Callocolax neglectus, Schmitz 1. c.}

Fronds minute, solitary or gregarious, parasitic on Callophyllis laciniata situated either on the edge or the surface of its fronds and frequently prominent on both sides of it, bilobed, palmate or irregular in shape, $2-4 \mathrm{~mm}$. in height; and about the same in breadth; tetraspores cruciate $18-20 \mu$ in diameter; cystocarps like those of Callophyllis, large, occupying almost the entire frond which then assumes a nearly globular shape; Antheridia unknown.

Berwick, I831, Dr. Johnston ; 1884, \&c., E. A. B. ; Arran, Miss E. Barton, 1892 ; Paignton, 1894 , and Falmouth, 1893 , T. H. Buff ham ; Weymouth, I893, E. M. Holmes; Swanage, E. A. B. Summer and autumn.

Hymenoclonium, nov. gen.

In 1859 the brothers Crouan described ${ }^{1}$, under the name Callithamnion serpens, a minute but interesting little Alga which they had found on bits of broken glass brought up by the dredge in Brest roads. They only obtained two specimens, and, so far as I am aware, until last winter the plant had not been again found. In December, I894, Mr. E. M. Holmes showed me a specimen of an Alga he had received from Plymouth, which in many respects differed from any known British Alga, and appeared to belong to an entirely new genus. Mr. Holmes very kindly gave me a portion of his specimen for examination, and requested me, if the plant were new, to describe it. I had intended to name the species after Mr. Holmes, but a careful examination of the description 
and plate of Callithamnion serpens given by the Crouans leads me to the belief that the plant found at Plymouth belongs to the same species. There can be no doubt, however, that the plant does not belong to the genus Callithamnion, and I propose to make a new genius Hymenoclonium for its reception.

This pretty little species creeps over the surface of the stone, or whatever it grows on, and adheres by its entire under surface, there being no rhizoids or anything of the sort. It is of a beautiful pink colour; and being branched like a Callithamnion or Ptilota, with the branches united by a hyaline membrane, it looks like a pink fern in miniature. The branches are all opposite, and either anastomose or fit between each other so as to form a nearly parenchymatous expansion, which retains its fern-like outline, however. There are no erect branches. Sometimes the main stem extends beyond the others and is bare of branches. According to the Crouans, tetraspores are formed from the contents of some of the cells of the main branches, but these I have not seen. The new genus may be described thus-

\section{Hymenoclonium, nov. gen.}

Fronds minute, adhering by the entire under surface; branches opposite, frequently anastomosing, united by a hyaline membrane into a pseudo-parenchymatous expansion; tetraspores (according to the Crouans) cruciate, formed from the cells of the main stem.

Hymenoclonium serpens (Crn.) = Callithamnion serpens, $\mathrm{Crn}$. Ann. Sc. Nat., fourth ser., vol. xii, p. 296, pl. 22, I, Figs. 4I-43 ; Florule du Finistère, p. I35.

Fronds minute, $2-4 \mathrm{~mm}$. in length, rose red or pink, adhering to the substratum by their whole under-surface, bi-pinnate, branches opposite united by a hyaline membrane into an irregular pseudo-parenchymatous expansion, upper portion of the main branches often naked; cells of the main stems 35-40 $\mu$ long and $10-12 \mu$ in diameter, those of the secondary branches 10-20 $\mu$ long, $8-10 \mu$ or more wide; 
apical cells of the main stems rounded, those of the secondary branches often pointed: chromatophores small, oval, many in each cell. According to the Crouans the cruciate tetraspores are situated in the continuity of the main stems.

Dredged from deep water in Plymouth Bay, December, 1894.

\section{EXPLANATION OF FIGURES IN PLATE XI.}

Illustrating Mr. Batters' paper on New British Marine Algae.

Buffhamia speciosa, Batt. Figs. I-IO.

Fig. I. Plant natural size in situ.

Fig. 2. A very young plant. $\times 200$.

Fig. 2b. Apex of young plant. $\times 500$.

Fig. 3. Apex of young frond ending in two hyaline hairs. $\times 500$.

Fig. 4. Surface of sterile frond showing chromatophores. $\times 500$.

Fig. 5. Section of frond before the appearance of the assimilatory filaments. $\times 250$.

Fig. 6. Base of frond showing the rhizoidal filaments. $\times 600$.

Fig. 7. Apex of young fertile frond. $\times 100$.

Fig. 8. Transverse section of fertile frond showing sporangia, assimilatory filaments, and hyaline hairs. $\times 400$.

Fig. 9. Longitudinal section of fertile frond. $\times 200$.

Fig. Io. Branched sporangium and assimilatory filaments. $\times 500$.

Myriotrichia densa, Batt. Figs. I I-I3.

Fig. I1. Tuft of peripheral branches with empty plurilocular sporangia. $\quad \times 300$.

Fig. 12. Tuft with both full and empty plurilocular sporangia and an unilocular sporangium. $\times 300$.

Fig. I3. Portion of peripheral branch with a branched plurilocular sporangium. $\times 300$.

Myriotrichia clavaeformis, Harv. var. subcylindrica, Batt.

Fig. 14. Three of the peripheral branches with unilocular sporangium. $\times 300$. 
Tellamia intricata, Batt. Figs. I5-17.

Fig. I5. Young plant showing the mode of branching. $\times 600$.

Fig. I6. Fertile frond. $\times 1500$.

Fig. I7. Section of the periostracum of Littorina obtusata, L. with Tellamia intricata filaments. $\times 500$.

Tellamia contorta, Batt. Figs. 18-24.

Fig. I8. Early stages in the development of $T$. contorta. $\times 150$.

Figs. 19-21. Stages in the development. $\times 500$.

Fig. 22. Portion of periostracum of Littorina with $T$. contorta seen from above. $\times 300$.

Fig. 23. Portion of the frond showing the horizontal branching and the enlarged cells. $\times 500$.

Fig. 24. Section of the periostracum of Littorina with $T$. contorta filaments. $\times 500$.

$$
\text { Callocolax neglectus, Schmitz. Figs. 25-29. }
$$

Fig. 25. Plant natural size in situ.

Fig. 26. Tetrasporic frond in situ. $\times 20$.

Fig. 27. Portion of the same. $\times 100$.

Fig. 28. Transverse section of a cystocarp. $\times 20$.

Fig. 29. Section through frond where it is united with the host-plant. $\times 200$.

Hymenoclonium serpens, Batt. Figs. 30, 3I.

Fig. 30. Portion of a frond seen from above. $\times 100$.

Fig. 3I. Tip of a frond showing chromatophores. $\times 700$. 
Annals of Botany.

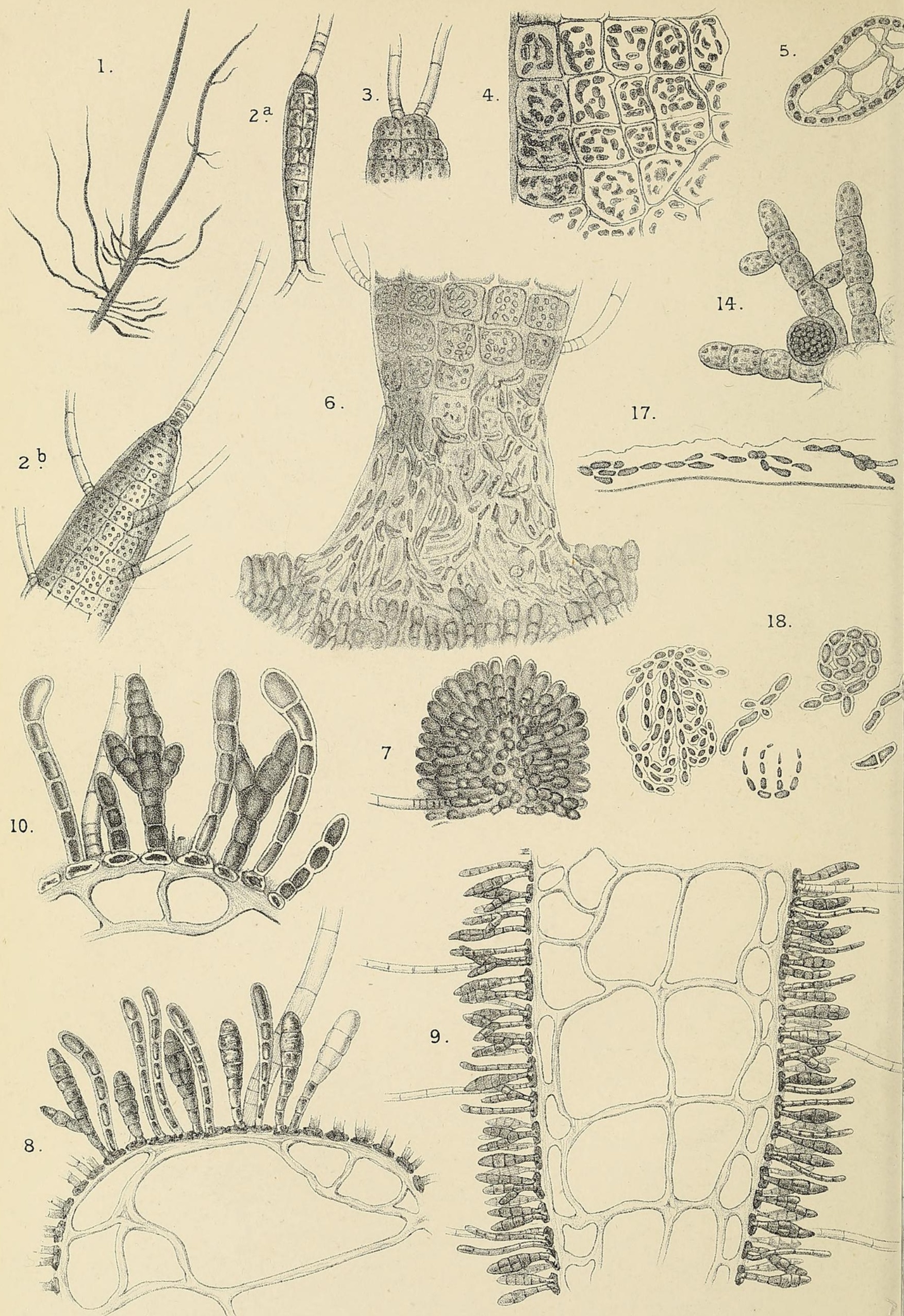

E.A.Batters del.

BATTERS. - NEW BRITISH MARINE ALGAE. 


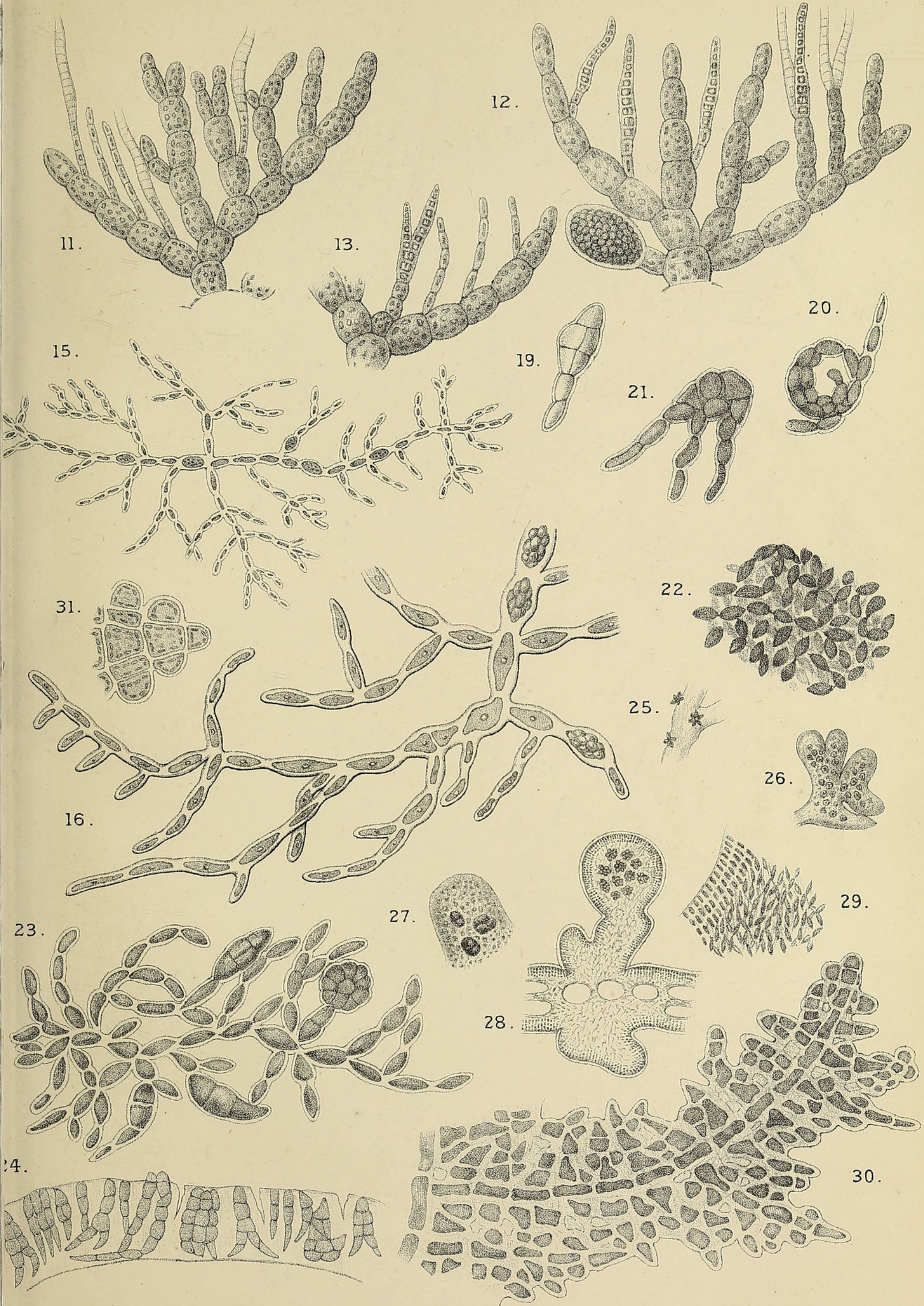




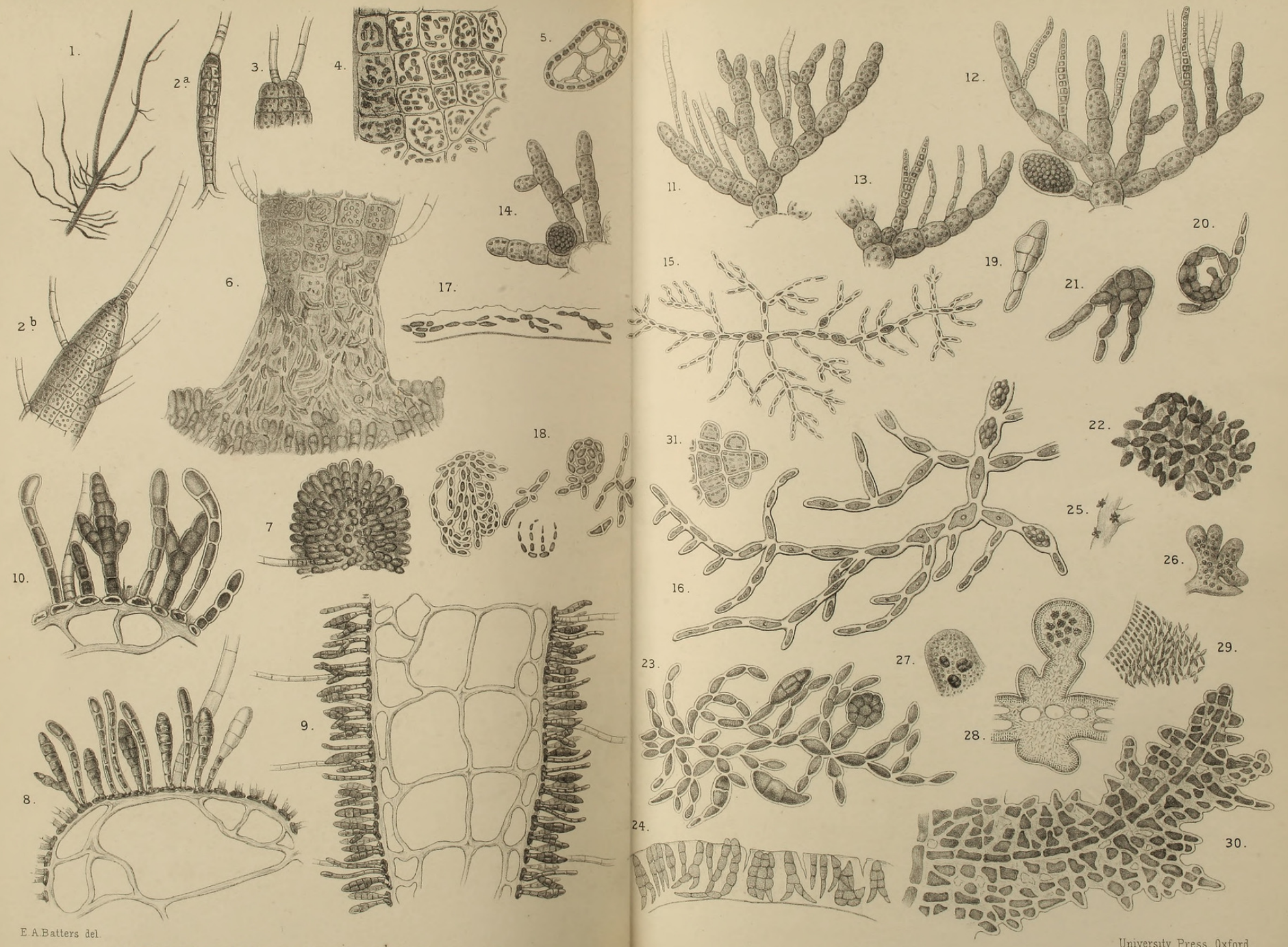




\section{$2 \mathrm{BHL}$ Biodiversity Heritage Library}

Batters, Edward Arthur Lionel. 1895. "On some new British marine algae." Annals of botany 9, 307-321.

https://doi.org/10.1093/oxfordjournals.aob.a090740.

View This Item Online: https://www.biodiversitylibrary.org/item/233478

DOI: https://doi.org/10.1093/oxfordjournals.aob.a090740

Permalink: https://www.biodiversitylibrary.org/partpdf/318380

\section{Holding Institution}

Smithsonian Libraries

\section{Sponsored by}

Biodiversity Heritage Library

\section{Copyright \& Reuse}

Copyright Status: Not in copyright. The BHL knows of no copyright restrictions on this item.

This document was created from content at the Biodiversity Heritage Library, the world's largest open access digital library for biodiversity literature and archives. Visit BHL at https://www.biodiversitylibrary.org. 